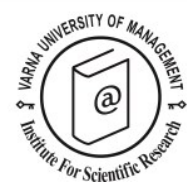

\title{
Tourism innovation networks: a regional approach
}

\author{
Filipa Brandão ${ }^{1 *}$, Carlos Costa² and Dimitrios Buhalis ${ }^{3}$
}

Received: 05/07/2017 Accepted: 30/10/2017

\begin{abstract}
1 Department of Economics, Management, Industrial Engineering and Tourism, GOVCOPP - Research Unit in Governance, Competitiveness and Public Policies, University of Aveiro. Campus Universitário de Santiago, 3810-393 Aveiro, Portugal, e-mail: filipa.brandao@ua.pt,Phone: +351 927162262

2 Department of Economics, Management, Industrial Engineering and Tourism, GOVCOPP - Research Unit in Governance, Competitiveness and Public Policies, University of Aveiro

3 Bournemouth University, eTourism Research Lab, Department of Tourism and Hospitality Management, Faculty of Management

* Corresponding author
\end{abstract}

\begin{abstract}
In the last decades, the innovation process experienced a significant evolution. From the early atomist models, the economy is moving towards systemic approaches based on interactive processes, strongly attached to the territories. Innovation networks are proliferating as the most suited framework for destinations to achieve a high innovation performance. However, there has been little research on the structure and dynamics of tourism innovation networks and how they can foster regional innovation. This paper applies Social Network Analysis to measure and identify the dynamics of cooperation within institutional tourism innovation networks and the role they play on tourism innovation. The study was applied to two Portuguese regions, Douro and Aveiro, where the top managers of institutions responsible for developing or supporting tourism innovation were surveyed. Results demonstrate that different social structures and patterns of cooperation create distinct impacts on regional innovation. It is concluded that tourism destinations characterised by diversified networks, i.e. networks comprising actors from different geographical locations and with distinct typologies, are in a better position to achieve a higher innovation performance. The paper advances strategic recommendations for tourism organisations to increase destinations' competitiveness, by further developing the necessary conditions for innovation to occur.
\end{abstract}

(C) 2018 Varna University of Management. All rights reserved

Keywords: Innovation, tourism, regions, networks, Social Network Analysis.

Citation: Brandão, F., C. Costa, D. Buhalis (2018) Tourism innovation networks: a regional approach. European Journal of Tourism Research 18, pp. 33-56

\section{Introduction}

Recently, networks of innovators are increasing significantly in all economic activities. Regional innovation networks are important mechanisms of growth for both individual businesses and for regions as a whole. Recent models approaching the innovation process include networks as central features, especially if the diversity of actors is assured. This occurs due to the advantages that networks bring to the 
innovation process, as they can create and offer unique value, access to resources, skills, and experience, timely access to external knowledge, improved trust, cooperation and social cohesion and rapid response to market opportunities, providing crucial conditions to innovate. This can be considered as a fundamental leverage for tourism SMEs by compensating the lack of internal R\&D and helping to overcome the risks and the high investment associated with the innovation process (Costa, Breda, Costa, \& Miguéns, 2008; Powell, Koput, \& Smith-Doerr, 1996; Vonortas, 2009; Acs \& Audretsch, 1988). It also prompts the creation and strengthening of important determinants of innovation, namely the flattening of organisational structures, the gaining of critical mass and dimension for SMEs, the alignment of management processes with innovation dynamics, the analysis of demand and identification of market opportunities, the development of human resources' competencies for innovating, the ability to overcome competitors and the access to diversified sources of knowledge. Considering the integrated and systemic nature of tourism destinations, perceived by tourists as an overall experience (Buhalis, 2000), the development of joint tourism innovations will increase their competitiveness in global markets.

Despite the acknowledged importance of networks for regional tourism innovation, research on the most appropriate social structures and their underlying regional dynamics is lacking. Most studies on tourism innovation are rooted in manufacturing approaches, neglect its relational nature (Narduzzo \& Volo, 2016) and are frequently aspatial (Polenske, 2007) as they disregard territorial dynamics and the role played by regional networks. The majority of tourism innovation research focus on firm-level conditions and factors or engage in qualitative methods (Hjalager, 2010). In fact, as concluded by Gomezelj (2016), out of all published research about hospitality and tourism innovation, only $6.6 \%$ address innovation systems, networks and clusters. The remaining $69.1 \%$ approach firm-level innovation, and $24.3 \%$ studies macro-level, or the effects of innovation on tourism destinations. There is, thus, a need for studies involving quantitative methods that analyse tourism innovation in a networked, systemic, and integrated perspective, focusing on regions and considering their functional dynamics.

To address these gaps and to contribute to the research on the role of networks within tourism innovation dynamics, this paper applies Social Network Analysis to characterise and discuss the patterns, structure, and dynamics of institutional innovation networks and how they can foster the development of regional tourism innovation. In order to obtain a basis for comparison, the study was applied in two Portuguese regions, Douro and Aveiro. Ultimately, it is intended to advance knowledge on the network dynamics that most positive and significantly contribute to the development of innovation at destination level, advancing policy and strategy recommendations that improve their efficiency and destinations' overall competitiveness.

\section{The Evolution of Innovation: Towards Networked Models}

The models explaining and supporting innovation processes have changed significantly in the last decades. Organisational forms, innovation inputs, drivers and barriers are evolving in result of different socioeconomic contexts, competition, market changes and of the dynamics between scientific knowledge and the economy. Early innovation models adopted linear processes, resulting from sequential sets of events occurring within firms. Innovation emerged through a linear progression starting from science or research and ending on marketing and sales. Science and R\&D were the privileged sources of innovation leading to the creation and commercialization of more successful products and services. Innovation was proactive to the market.

Kline and Rosenberg (1986) pointed some limitations to this model, one of which was the fact that innovation should first consider market needs. Consumers should be the primary source of innovation. The second generation of innovation models (demand-pull), although still linear, seemed to overcome this placing customers as the providers of guidelines for $R \& D$, which gained a merely reactive role in the 
innovation process. This practice led firms to perform mostly incremental innovations and to lose their ability to adapt to radical market changes (Rothwell, 1994).

In response to the limitations of linear models against market changes, Kline and Rosenberg's Chain-Linked Model (1986) and Rothwell's Coupling Model (1994) approached innovation as the result of an interactive process, a set of intra and extra-organisational communication paths linking together firms, scientific community and the marketplace, moving away from linear constructs.

More recent approaches are built on the relevance of networking. Beyond the integration of their functional units, firms need to reinforce their connections to other organisations taking part on the system of innovation. Interaction and knowledge sharing are necessary, especially those deriving from linkages with other sources of knowledge such as firms, universities, research centres, users, suppliers. Information sharing is important, however, the acknowledgement of the importance of tacit knowledge for innovation led to a focus on the mechanisms that enable the creation, transfer, and use of all knowledge types. Recent models are thus based on knowledge and connectivity (Chaminade \& Roberts, 2002) where innovation is understood as an interactive and integrated phenomenon.

As stated by Cooke and Morgan (1998, p.17), "the wider environment of the firm - the social and political system in which it is embedded and with which it interacts - can play a vital role in facilitating (or frustrating) its learning capacity". This emphasises that innovation is a socially and institutionally embedded process, endowed with a systemic nature. Furthermore, Fagerberg (2006, p. 4) argues that firms rarely innovate in isolation, since innovation "results from continuing interaction between different actors and organisations", highlighting the fundamental role of networks and inter-firm relationships. These relationships among economic agents are crucial for knowledge creation and transfer and for collective learning, central elements of systemic innovation (Lundvall, 1992). These dimensions are on the basis of the territorial innovation models and partly explain why organisations agglomerate and create networks in order to innovate.

\section{Networks as the Core of Regional Tourism Innovation}

The application of network theory and social network analysis methods to the study of tourism is recent. Nonetheless, several authors have been studying different dimensions of tourism dynamics under the light of network analysis, contributing, for instance, for regional tourism planning (Costa, 1996) to the understanding of the role and dynamics of networks at local destinations and local tourism businesses (Breda, Costa, \& Costa, 2005, 2006; Costa et al., 2008; Gibson, Lynch, \& Morrison, 2005; Lazzeretti \& Petrillo, 2006; Michael, 2007; Kathryn Pavlovich, 2003; Petrillo \& Swarbrooke, 2005; Presenza \& Cipollina, 2010; G. Saxena, 2005; Saxena \& Ilbery, 2008; Scott, Baggio, \& Cooper, 2008; Scott, Cooper, \& Baggio, 2008; Swarbrooke, Smith, \& Onderwater, 2004; Tinsley \& Lynch, 2001), for tourism policy and governance (Baggio, Scott, \& Cooper, 2010a; Bramwell, 2006; Dredge, 2006; Kathryn Pavlovich, 2008; Volgger \& Pechlaner, 2015), for promoting and developing tourism destinations (Aureli \& Forlani, 2015), for understanding the destination choice process (Karl \& Reintinger, 2017), for analyzing the relationships between networks and tourism innovation (Dredge, 2005; Novelli, Schmitz, \& Spencer, 2006; Paget, Dimanche, \& Mounet, 2010; Sørensen, 2007; Zach \& Hill, 2017), knowledge transfer (Baggio \& Cooper, 2008, 2010; Weidenfeld, 2013) and learning (Booyens \& Rogerson, 2017; Halme, 2001) within networks.

Research on innovation networks is of paramount importance, as the absence of relationships between firms and organisations hampers the development of systemic innovation. Tourism firms are the responsible for introducing innovations in the marketplace, while tourism organisations create the necessary conditions for the development of innovation by firms. They should all be engaged in networks of cooperation for this to occur. The analysis of the established relationships is crucial for understanding the dynamics of innovation systems (Archibugi, Howells, \& Michie, 1999) as these are 
supported by networks. "Networks constitute the new social morphology of our societies (...) they are the new structure of dominant functions and processes" (Castells, 2010, pp. 500-501). A network is defined as a group of actors (persons, teams, places, organisations) connected by a set of ties (Borgatti \& Foster, 2003). (Costa, 1996, p. 148) advances a comprehensive approach to the concept and defines networks as:

“(...) an organisational structure whose operating philosophy may be placed between Weber's bureaucratic model and the neoliberal or market philosophy. Networks are based on two or more (usually administrative independent) organisations which decide, by a formal or informal commitment, to engage in a medium- or long-term cooperation process (...). A network is, therefore, underpinned by the premises that every organisation depends on the success of others and also that competition must be viewed beyond the region where an organisation is located".

The study of networks assumes that individuals or organisations do not act in isolation and that the pattern of relationships developed with other actors is strongly influenced by their behaviour (Considine, Lewis, \& Alexander, 2009; Scott, Baggio, et al., 2008; Baggio, 2017). Thus, different network structures will result in different outcomes (Favre-Bonté, Gardet, \& Thevenard-Puthod, 2016) namely in terms of competitive advantages, economic behaviour, social capital, knowledge transfer and, subsequently, different innovation patterns. Several authors acknowledge that innovative performance is enabled by interactions resulting from networking behaviour among regional actors and between these and external partners (Booyens \& Rogerson, 2016; Hjalager, 2014; Weidenfeld \& Hall, 2014).

The engagement in networks brings several benefits to organisations. According to Child, Faulkner, and Tallman (2005), being part of such a social structure may (i) reduce the uncertainty of market relations, as these are based on trust; (ii) make production and allocation of resources more flexible; (iii) improve and expand firms' endogenous 36 capacities; (iv) give immediate responses to market challenges due to the availability of resources and flexibility of processes; ( $v$ ) provide access to exogenous resources and skills and (vi) provide access to information and knowledge. Saxena and Ilbery (2008) add that networks enable actors to search for, obtain and share resources, engage in cooperative and collective actions in order to achieve common goals, exchange and diffuse ideas and mobilise resources.

The social world is constructed as a network of communications. In what regards innovation, ideas exist and come to life within and in result of such networks. These include connections between firms, government agencies, interest groups and social movements (Considine et al., 2009). "Networks provide access to more diverse sources of information and capabilities than are available to firms lacking such ties, and, in turn, these linkages increase the level of innovation inside firms" (Powell \& Grodal, 2006, p. 68).

Network relationships can create and provide firms with unique and non-replaceable value as well as access to incomparable resources and capabilities of other organisations, giving them crucial conditions to innovate. Networks grant timely access to external knowledge and resources otherwise unavailable to a single firm and at the same time they allow the testing of internal expertise and learning abilities (Costa et al., 2008; Powell et al., 1996; Vonortas, 2009). This is particular relevant for most central actors who, in result of their privileged position, are in better conditions to access the network resources and thus may have a higher innovation performance (Liu, Madhavan, \& Sudharshan, 2005). Acs and Audretsch (1988) highlight that knowledge spillovers resulting from regional networks compensate the lack of R\&D by SMEs that frequently do not have the financial or institutional means to do it. They therefore engage in collaborative research activities with universities, research centres or spin-offs. This is particularly relevant for services, in general, and tourism in particular, as it is mainly composed of SMEs. In addition to the creation and transfer of knowledge related to innovation, networks allow firms to learn how to innovate synergistically and to 
develop routines to that effect, such as technology transfer and to locate themselves in strategic network positions (Powell et al., 1996). Networks also foster trust and social cohesion due to the sharing of values, goals, and ways of working which facilitates collective innovation (Hotz-Hart, 2000). However, for Camagni (1991), while regional innovation networks improve the access of small businesses to experience and knowledge, their true strength is in their ability to provide ties to global networks.

\section{Tourism Innovation Networks}

In the last decades, networks of innovators and the diversity of actors and relationships involved in the innovation process have suffered a considerable increase (Mowery, 1999; Powell, 1990). According to Lundvall and Borrás (1997, p. 106) “(...) more and more of the innovation process takes place through networking. (...) only a small minority of firms and organisations innovate alone, and most innovations involve a multitude of organisations"

In tourism, the situation is not different. Zach (2016) confirms that collaboration for innovation is a major driver of innovation success in hospitality and tourism businesses. Sundbo, Orfila-Sintes, and Sørensen (2007, p. 90) argue that innovation in tourism requires networks and co-operative systems and that territories assume a central role, as it should be viewed "from the destination perspective, where tourists come to a destination and the tourist firms are mutually dependent on developing common destination innovations". Regional innovation networks are important mechanisms of growth for both individual businesses and for regions as a whole. This idea was initially developed by GREMI with the innovative millieux model (Aydalot, 1986), and followed by other scholars working on innovation networks and regional development.

Despite being a recent area of research, the importance of networks in tourism is vast and has been gaining significance, especially concerning the development of innovation. Collaboration between tourism organisations increases the innovative capacity and performance of tourism industry, especially due to the transfer of knowledge and experiences (Pechlaner, Fischer, \& Hammann, 2006; Rønningen, 2010; Sørensen, 2007). Networks are thus antecedents of tourism innovation, and a necessary condition for regional innovation to occur.

Tourism is fragmented in nature, involving several complementary activities that bundle together in an integrated experience at destination level. According to the Tourism Satellite Account Framework (UNSD, EUROSTAT, OECD, \& UNWTO, 2008), the tourism industry comprises a set of characteristic activities, namely businesses of accommodation, food and beverages, transport, travel agencies and tour operators, cultural, sports and recreational services. Besides tourism firms, there are public authorities at national, regional and local levels, DMO's, business and professional associations, that have an important role in destination management and governance. In this regard, networks provide important benefits, as they compensate this segmentation by bringing together these tourism stakeholders and providing tourists with comprehensive experiences (Scott, Baggio, et al., 2008) by empowering them to innovate in cooperation, synergistically. Moreover, the tourism business environment is turbulent and very competitive, meaning that growth or even survival of firms might depend on collective action (Scott, Baggio, et al., 2008).

A study on Portuguese tourism SMEs unveils a gradual association to networks, as it brings higher representativeness and credibility, influence near governmental bodies, the provision of technical support and training, access to updated information on tourism, knowledge exchange, the possibility of engaging in strategic partnerships, access to institutional and legal support and joint promotion (Costa et al., 2008). Moreover, tourism management and planning are developed within comprehensive, participatory, and informed approaches supported by a wider variety of participants and are conceived in a long-term sustainable economic view (Costa, 1996).

Tinsley and Lynch (2001) believe that, when addressing tourism networks, the destination 
should be regarded as a whole system. Networks are the frameworks that bind the place and people together, going beyond the destination to regional, national, or even international level. Thus, the broader the networks an organisation is affiliated in, the more experiences, competencies and opportunities are derived by it, which will increase innovation performance. The access to more varied activities, experiences and people will enlarge the pool of available resources, especially the knowledge base. Multiplex ties deepen relationships, commitment, and knowledge sharing (Powell \& Grodal, 2006). In this case, tourism firms and organisations are able to access and use valuable knowledge about markets and trends, funding, they will have the opportunity of jointly create new products and services, or develop marketing strategies, create organisational structures that improve destinations' overall functioning and competitiveness.

A highly-discussed topic within innovation networks is about their structure in terms of density and strength of ties. Dense versus sparse networks, strong versus weak ties (Granovetter, 1983) provide different benefits and distinct innovation performance. Cohesive or dense networks occur when all actors are connected to each other. This creates the atmosphere for higher levels of trust and norms of reciprocity (Coleman, 1988). In result, it facilitates both the dissemination of tacit knowledge quickly and reliably throughout the network (Uzzi, 1997), as well as the operation of governance mechanisms that promote information flow and knowledge sharing (Krackhardt, 1992). On the other hand, too closed networks can place its members in a lock-in scenario. The over-embeddedness in a particular and limited network prevents its actors from searching from new partners outside the network and thus accessing to new knowledge and ideas. They become locked in those strong ties, hampering their potential for innovation (Clar, Sautter, \& HafnerZimmermann, 2008; Uzzi, 1997). External knowledge from extra-regional relationships (national and international) plays a major role in learning and innovation, while networks based on local and regional actors can lead to the underdevelopment of regional innovation systems (Booyens \& Rogerson, 2017; Fitjar \& Rodríguez-Pose, 2015; Hoarau \& Kline, 2014). Conversely, a network characterised by a sparse structure with weak ties will benefit from the privileged access to new and unique knowledge and innovation opportunities, namely through brokers filling in structural holes (Burt, 1992; Granovetter, 1973). In this context, people with different backgrounds and perspectives or working in different industries will exchange information, learning from each other, and enhancing the potential for new combinations of knowledge into innovative products and services. Nonetheless, this type of network structure may bring detrimental effects to innovation, as it prevents strong ties which are necessary to transfer tacit knowledge. In sum, an adequate combination of both strong and weak ties within the same network seems to be the most fruitful scenario for innovation.

Within regional tourism destinations, institutions are crucial in creating the conditions for innovation networks to develop and succeed. They provide the support framework that influences the dynamics of regional innovation systems and may be co-creators of innovation (Amin \& Thrift, 1995). They influence innovation within tourism destinations by defining policies, laws, rules, conventions, behaviours, funding, identifying market opportunities, shaping the local context for knowledge sharing, creating knowledge spillovers and developing the capacity of association of the system (Cooke \& Morgan, 1998; Howells, 2002). They also act as repositories of knowledge and identifiers of new opportunities due to their position as intermediaries as they frequently contact with external actors (as part of broader associations) and simultaneously close to local firms. For these reasons, it is relevant to broaden the knowledge on the role that institutional innovation networks play on regional tourism innovation.

\section{Research Methods}

This research applies a quantitative approach to social network analysis, aiming to unveil the structure, patterns, and dynamics the underlying tourism innovation networks, namely the relationships established among institutions 
towards the development of regional tourism innovation. Social network analysis presents a distinct research perspective within social sciences by considering that individual features arise from the relational properties of a social structure (Knoke \& Kuklinski, 1982; Wasserman \& Faust, 1994).

Network properties help to define the network structure and provide the necessary measures to characterise the relationships developed within it. The network structure "(...) is a configuration of relations in an institutional environment. It is both the basis and the result of processes of interaction. (...) It enables and constrains action, and action (re)constructs structure" (Nooteboom, 2004, p. 70). Knoke and Kuklinski (1982) noted that the structure of the network and the relations among actors have significant behavioural, perceptual, and attitudinal consequences for individual units and for the entire system. Some authors divide network properties in relational, when they inform about the ties and relationships developed among actors, and positional, such as those who enlighten about which actors occupy which positions in a network (Haythornthwaite, 1996).

In order to analyse the structure of relationships among regional institutions, two properties are measured: centrality and connectivity. Centrality (or prestige or prominence) relates to which actors are important in a network and which are not, and includes central measures and analysis of network structure. Central positions in networks are strongly connected to social capital, because a central actor has higher access and control over information and resources, as it entails a large number of connections with other nodes. An actor will thus occupy a strategic position if it can reach other actors on short paths. Central or prominent actors are those engaged in many ties/ relationships with others, regardless of being the recipient or the source of the relationship (nondirectional ties), and are the most active in the network. Central actors can maintain, create or prevent the creation of information channels. Centrality has implications for power, not only due to the access and control of information, but also in what relates to the access to alternative actors in the network, reducing the dependence over one or few network nodes (Degenne \& Forse, 1999; Hanneman \& Riddle, 2005; Haythornthwaite, 1996; Kolaczyk, 2009; Koput, 2010; Nooteboom, 2004; Scott, 2000; Wasserman \& Faust, 1994). Centrality is measured by the degree, closeness and betweenness, which inform about the actors' location in the network, and network centralisation/ group degree, which combines individual measures to obtain a group level analysis (Wasserman \& Faust, 1994). In order to perform a solid analysis on actor and network centrality, the outputs of these measures should be interpreted together. For instance, an actor may have a low degree centrality, but a high betweenness, which grants him a privileged strategic position as a broker or intermediary having high access to new knowledge and performing an important role in innovation diffusion.

Networks can also be evaluated in terms of their levels of connectivity or cohesion, which relates to the extent to which subsets of actors are cohesive. A network is connected if there is a path between each pair of nodes, meaning that all pairs of nodes are reachable. Network cohesion can be analysed by using measures such as density, reachability or geodesic distance. Different levels of connectivity have distinct impacts on how information, knowledge and innovation flow easily within the network and reach all actors (Wasserman \& Faust, 1994). For instance, lower distance and reachability will facilitate the diffusion of innovations and information, increase levels of trust, homogeneity and the strength of the relation (higher proximity and lower number of paths between two actors represent a stronger relation).

An exhaustive survey on social network analysis metrics was conducted. Table 1 presents the metrics used to study centrality and connectivity. These specific metrics were carefully selected among many others due to the fact that they provide important information for the analysis of innovation, such as the most relevant actors within regional tourism innovation processes, the patterns of cooperation between institutions and the role of geographic proximity and external links, or the embeddedness of regional tourism innovation. 
Tourism innovation networks: a regional approach.

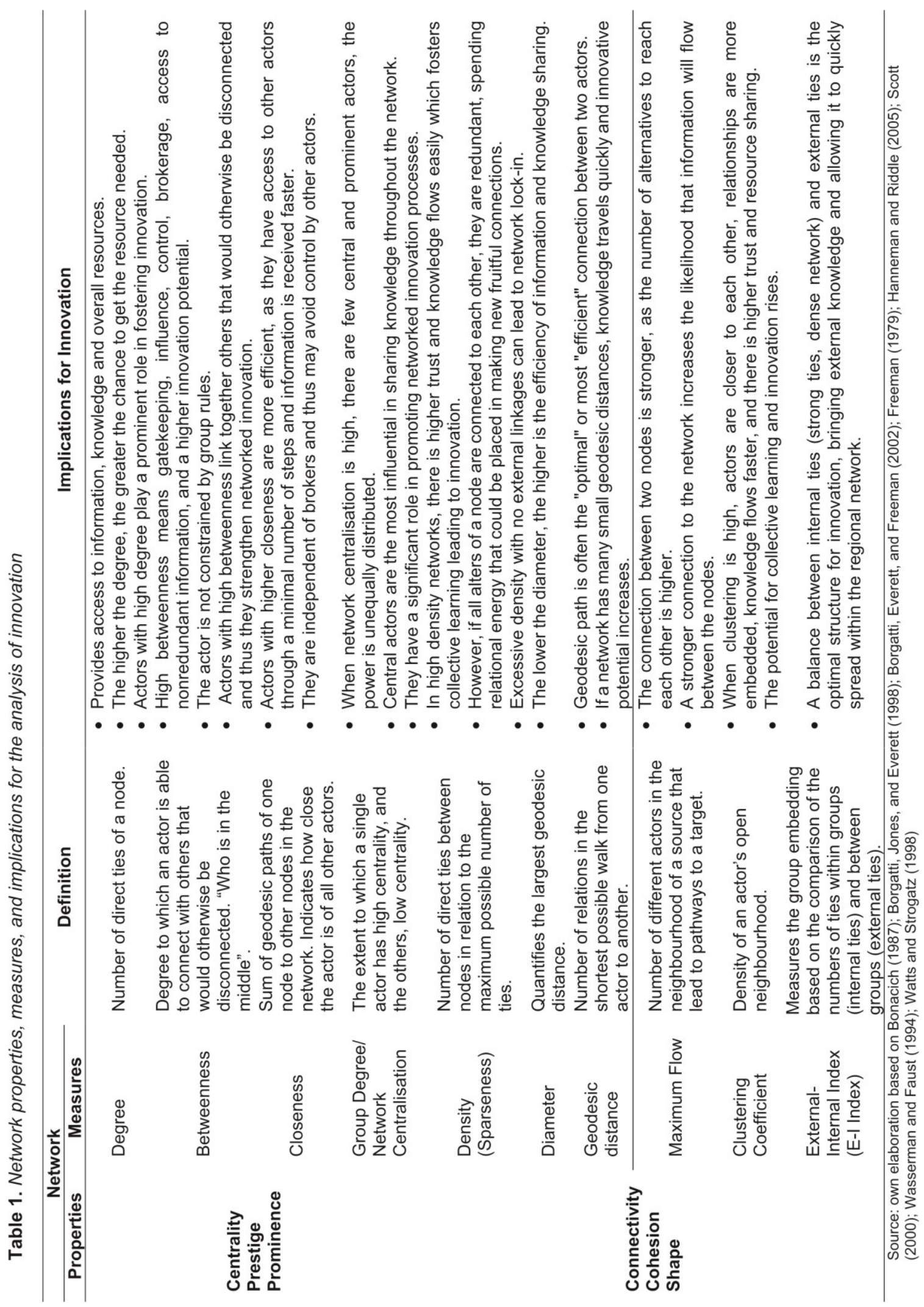


Bearing this in mind, an empirical study was conducted, directed at top managers of regional institutions that are on the interface of tourism innovation, and who assume specific functions regarding the support or development of tourism innovation. Considering that the relationships established among institutions are the core of regional innovation systems, the main objective of the survey was to obtain relational data to characterise the institutional tourism innovation networks and identify their impact on the development of innovation in the overall destination.

Data collection was completed through a structured questionnaire completed by the interviewer. Specifically, it was gathered relational information regarding tourism innovation processes according to the networking patterns, the geographical scope of cooperation and the selected partners, and to advance knowledge on the relation between different network patterns and dynamics, and destinations' innovation performance. In order to do this, top managers were asked to identify: (i) if their institutions are/were involved in the development of any tourism innovation projects in the last three years; (ii) in that context, with which institutions there has been cooperation; (iii) the geographical scope of these institutions; and (iv) the specific purpose of cooperation (knowledge creation, knowledge exchange, new product development, new process development, new marketing strategy).

The surveyed institutions were carefully selected according to Malerba's (2005) definition of regional innovation systems. These include universities, research centres, financial institutions, government agencies, associations and groups of organisations (industry associations). In order to specifically identify the institutions falling under these categories and in the interface of regional tourism innovation, we resorted to the composition of the Regional Tourism Board of both regions. Besides these, other institutions were also identified as influencing the dynamics of regional innovation (such as spin-off firms, and innovation support agencies) and were thus included in the sample. The identified institutions were subsequently grouped into (i) knowledge and education institutions; (ii) tourism public organisations; (iii) tourism business associations; and (iv) innovation agencies in order to analyse the networked innovation dynamics between different groups of organisations. The description of the participants is detailed in table 2. Initially, a total of 15 institutions in Douro and 15 in Aveiro were listed and interviewed. A snowball sampling method was applied, which implies that each actor is asked to point further participants in the phenomenon under analysis (Carlsson, Jacobsson, Holmén, \& Rickne, 2002). In result, the core organisations provided information on the relational behaviour of 55 actors in Douro and 87 in Aveiro, which allowed us to build comprehensive innovation networks.

In order to obtain reference values (rather than just comparing the networks), a random network of the same size and order was computed for both regions, following the Erdös Rényi method, as suggested by Baggio et al. (2010a) and by Baggio (2008). Following the method used by the authors, the reference values were obtained by calculating the average of ten random networks using the Erdös-Rényi model, where the networks comprise a specific number of nodes (matching the observed network) and the links are placed randomly between pairs of nodes, assigning each dyad a uniform probability $(p)$ of having a tie based on the number of observed ties. The results of the metrics computed for the real networks were then compared to the reference (null) model.

Two Portuguese regions (Douro and Aveiro) were chosen due to the interest in comparing destinations with different tourism products and in distinct stages of development, which results in different business structures, governance systems and interaction among organisations. Douro is located in Northern Portugal and comprises 19 municipalities. It is in an early stage of tourism development, although very acknowledged nationally and internationally especially due to wine tourism and the Douro river cruises. Aveiro locates in Central Portugal, by the Atlantic Ocean embracing 12 municipalities. It is in a more advanced stage of development than Douro. The region is highly polarised by the city of Aveiro, where the Ria 
Table 2. Surveyed institutions in the regions of Douro and Aveiro

\begin{tabular}{|c|c|c|}
\hline Group & Douro & Aveiro \\
\hline $\begin{array}{l}\text { Knowledge } \\
\text { and education } \\
\text { system }\end{array}$ & $\begin{array}{l}\text { - University of Trás-os-Montes e Alto } \\
\text { Douro } \\
\text { - Research Centre for Transdisciplinary } \\
\text { Studies for Development } \\
\text { - Polytechnic Institute of Viseu } \\
\text { - Hospitality and Tourism Vocational } \\
\text { School of Douro }\end{array}$ & $\begin{array}{l}\text { - University of Aveiro } \\
\text { - Research Centre on Governance, } \\
\text { Competitiveness and Public Policies - } \\
\text { Tourism Group } \\
\text { - IDTOUR - Tourism applied research } \\
\text { spin-off } \\
\text { - Tourism Vocational School of Aveiro } \\
\text { - Tourism Vocational School of Vagos }\end{array}$ \\
\hline $\begin{array}{l}\text { Tourism public } \\
\text { agencies }\end{array}$ & $\begin{array}{l}\text { - Sub-regional Tourism Board } \\
\text { - Regional Coordination and } \\
\text { Development Commission for } \\
\text { Northern Portugal } \\
\text { - Association of Municipalities of the } \\
\text { Douro Region } \\
\text { - Douro and Porto Wines Institute } \\
\text { - Regional Directorate for Culture of } \\
\text { Northern Portugal }\end{array}$ & $\begin{array}{l}\text { - Regional Tourism Board } \\
\text { - Regional Coordination and } \\
\text { Development Commission for Central } \\
\text { Portugal } \\
\text { - Association of Municipalities of the } \\
\text { Aveiro Region } \\
\text { - Regional Directorate for Culture of } \\
\text { Central Portugal }\end{array}$ \\
\hline $\begin{array}{l}\text { Tourism } \\
\text { business } \\
\text { associations }\end{array}$ & $\begin{array}{l}\text { - Portuguese Association for } \\
\text { Hospitality, Restaurants and Similar } \\
\text { - Association of Tourist Businesses of } \\
\text { Douro } \\
\text { - Association of Hospitality and } \\
\text { Tourism Businesses of Douro } \\
\text { - Business Association } \\
\text { - Wine Route Association } \\
\end{array}$ & $\begin{array}{l}\text { - Portuguese Association for } \\
\text { Hospitality, Restaurants and Similar } \\
\text { - Wine Route Association } \\
\text { - Rural Tourism Association } \\
\text { - Industrial Association of Aveiro } \\
\text { Region }\end{array}$ \\
\hline $\begin{array}{l}\text { Innovation } \\
\text { agencies }\end{array}$ & - Regional Innovation Centre & $\begin{array}{l}\text { - Aveiro Network for Innovation } \\
\text { - Agency for Competitiveness and } \\
\text { Innovation }\end{array}$ \\
\hline Total & 15 & 15 \\
\hline
\end{tabular}

(estuary) has always influenced the regional economy and development, the industrial and agricultural activities and the landscape. Tourists are attracted by the beaches, local gastronomy, boiling springs, cultural heritage, by rural and natural areas and by the university.

\section{The Structure of Tourism Innovation Networks}

Structure and Patterns of Cooperation towards Innovation

In order to fulfil the research objectives, it was important to know the innovation performance of both regions. However, this study in particular, aims at analysing the networked innovation of regional tourism destinations based on a broader research about regional tourism innovation systems. For this reason, innovation performance of tourism firms is not explored in detail. However, a complementary analysis was conducted to measure the number and type of innovations introduced by tourism firms in the former three years, following the methodology applied in the Community Innovation Survey (Eurostat, 2016). The results demonstrate that Aveiro presents a higher innovation performance, as $84.4 \%$ of the firms are innovative, against $77 \%$ in Douro. Aveiro also has a higher rate of major innovators, that is, firms introducing tourism products that are entirely new to the market (56\% in Aveiro and $43.7 \%$ in Douro). As previously mentioned, the regional innovation dynamics demonstrated by firms, especially the characteristics of innovation networks, are strongly influenced by the conditions provided by regional institutions (Amin \& Thrift, 1995; Cooke \& Morgan, 1998; Howells, 2002). Bearing this in mind, the innovation performance of tourism firms may be the result of the conditions developed within institutional 
networks, as they can foster or constraint it. Therefore, these results may support the network analysis and to conclude on the consequences of the demonstrated patterns in tourism regional innovation.

Table 3 depicts the mains characteristics of both networks. Although integrating less municipalities and despite the fact that both regions have a similar number of tourism firms, the innovation network of Aveiro is larger than Douro, as it registers 87 actors (or nodes) engaged in 314 ties, against the 55 actors in Douro, representing 274 ties. However, actors from Douro have a higher average degree (average number of links per node) regarding tourism innovation, which means they, in average, they establish more connections to develop innovation. If we consider the networks' diameter, it can be concluded that they are lower than expected in both regions, which means that there is a high efficiency of resources sharing. Nonetheless, Aveiro appears to be more efficient due to the larger difference between the random and real network diameter. These results are reinforced by the average path length. Both networks are fully connected, prompting the flow of knowledge and ideas which are likely to reach every node and engage all actors in the innovation process.

Their composition is also distinct, as it was expected. In fact, our results confirm the finding of Favre-Bonté et al. (2016), that conclude that innovation networks differ in terms of the partners and geographical scope. Douro is somewhat unbalanced in terms of the type of actors comprising it, as more than half are public institutions, only $18 \%$ are business associations and $16 \%$ are knowledge producers (Figure 1). This scenario, despite not being the most advantageous, is explained by the fact that Douro is at an earlier stage of tourism development, and had a significant state intervention through a tourism development plan that framed funding and destination planning, organisation and promotion. Public organisations perform a leverage role with the aim of fuelling the intervention of private sector organisations and attracting investments into the area.

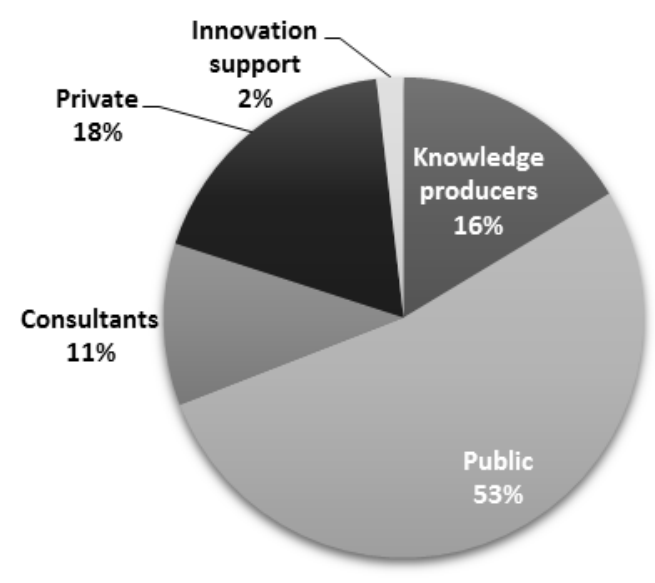

Figure 1. Composition of the innovation network of Douro

In Aveiro, public agencies stand out with $45 \%$ of total, but are followed by knowledge organisations. By representing $25 \%$ of network actors, it indicates that scientific knowledge and tourism education are valued and perform a significant role in regional tourism innovation (Figure 2). This situation is fostering the creation and dissemination of new knowledge throughout the network, propelling innovation, which, alongside the high number of international and national organisations, is fundamental for constant innovation.

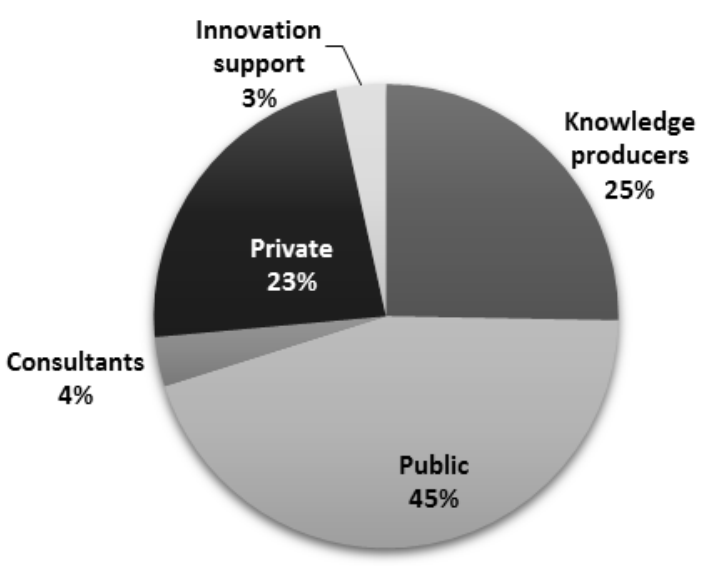

Figure 2.Composition of the innovation network of Aveiro 
Tourism innovation networks: a regional approach.

Table 3. Main metrics of Aveiro and Douro's tourism innovation networks (real and random)

\begin{tabular}{lcccc}
\hline Metrics & $\begin{array}{c}\text { Douro } \\
\text { Real } \\
\text { Network }\end{array}$ & $\begin{array}{c}\text { Douro } \\
\text { Random } \\
\text { Network }\end{array}$ & $\begin{array}{c}\text { Aveiro } \\
\text { Real } \\
\text { Network }\end{array}$ & $\begin{array}{c}\text { Aveiro } \\
\text { Random } \\
\text { Network }\end{array}$ \\
\hline Order (nodes) & 55 & 55 & 87 & 87 \\
Size (ties) & 274 & 274 & 314 & 314 \\
Density & 0.092 & 0.092 & 0.042 & 0.042 \\
$\begin{array}{l}\text { Average Degree } \\
\text { Network }\end{array}$ & 4.98 & 4.98 & 3.61 & 3.61 \\
$\begin{array}{l}\text { Centralisation } \\
\text { Diameter }\end{array}$ & $69.22 \%$ & $9.07 \%$ & $44.5 \%$ & $6.18 \%$ \\
$\begin{array}{l}\text { Clustering } \\
\text { Coefficient }\end{array}$ & 4 & 5 & 5 & 8 \\
\hline
\end{tabular}

When analysing the sharing of knowledge for innovation between tourism industry and science, Hoarau and Kline (2014) also concluded that tourism academics and practitioners effectively share both tacit and codified knowledge, and that knowledge used for innovation is co-created alongside stakeholders that are external to the organisation. Private business associations are also expressive with $23 \%$ of total actors. In both networks, consultants and innovation support agencies are less significant.

The density of the network informs on the strength of the relations, the pace through which knowledge spreads, and the levels of social capital or constraint (Hanneman \& Riddle, 2005). In the tourism innovation network of Douro, $9.2 \%$ of all possible connections are effectively established among the actors. Aveiro encompasses a lower density, of $4.2 \%$. Although these values appear to be rather low, one may refer the study of Elba and Fiji tourism networks, whose density was respectively of $0.3 \%$ and $0.2 \%$ (Baggio, Scott, \& Cooper, 2010b) or of four cases in Australia, where the results are closer to ours, ranging between $6 \%$ and $14 \%$ (Scott, Cooper, et al., 2008). If all actors located outside the region are removed, the density of both networks reach about $12 \%$. The level of cohesion is thus higher among actors that are physically close, confirming the regional embeddedness of tourism innovation.

\section{Networks' Topography: Centrality and} Cohesion

Most central actors in networks have higher prominence, control and access to overall resources and are also less dependent on other actors. Both networks present a significantly higher centralisation of power than would be expected, indicating that there are few prominent actors much more powerful that others and therefore, positional advantages are unequally distributed. Thus, the efforts conducted towards tourism innovation are highly concentrated in a few organisations, a situation more noteworthy in Douro than in Aveiro, where power is more dispersed. A high centralisation degree may foster the coordination of network members, as they share the same principles and objectives. It is important to control and undertake the necessary activities towards the development of innovation, especially in an industry with a high diversity of actors and businesses. Central actors encompass the ability of facilitating and promoting the interaction among all the actors in the network (Granovetter, 1973). Actors with high degree centrality have the highest number of direct connections and therefore have more powerful positions in the network. Empirical evidence supports that highly central actors are in a good position to innovate due to (i) the access to a significant quantity and diversity of resources; (ii) the location at the confluence of several information and knowledge sources; and (iii) the fact that they are endowed with a status that impels them to innovate first (Liu et 
Brandão, F., C. Costa, D. Buhalis (2018) / European Journal of Tourism Research 18, pp. 33-56

al., 2005). There is a strong and positive relationship between degree centrality and innovative capacity of organisations. While analysing the most central actors in Douro six stand out, reaching nearly half $(49.8 \%)$ of total degree centrality of the Douro tourism innovation network (Figure 3 and Table 4).
These are mainly public institutions with a strong intervention in regional tourism development and management. This situation confirms the results of Zach (2016), whereby most tourism innovation was initiated by the focal Destination Management Organisation.

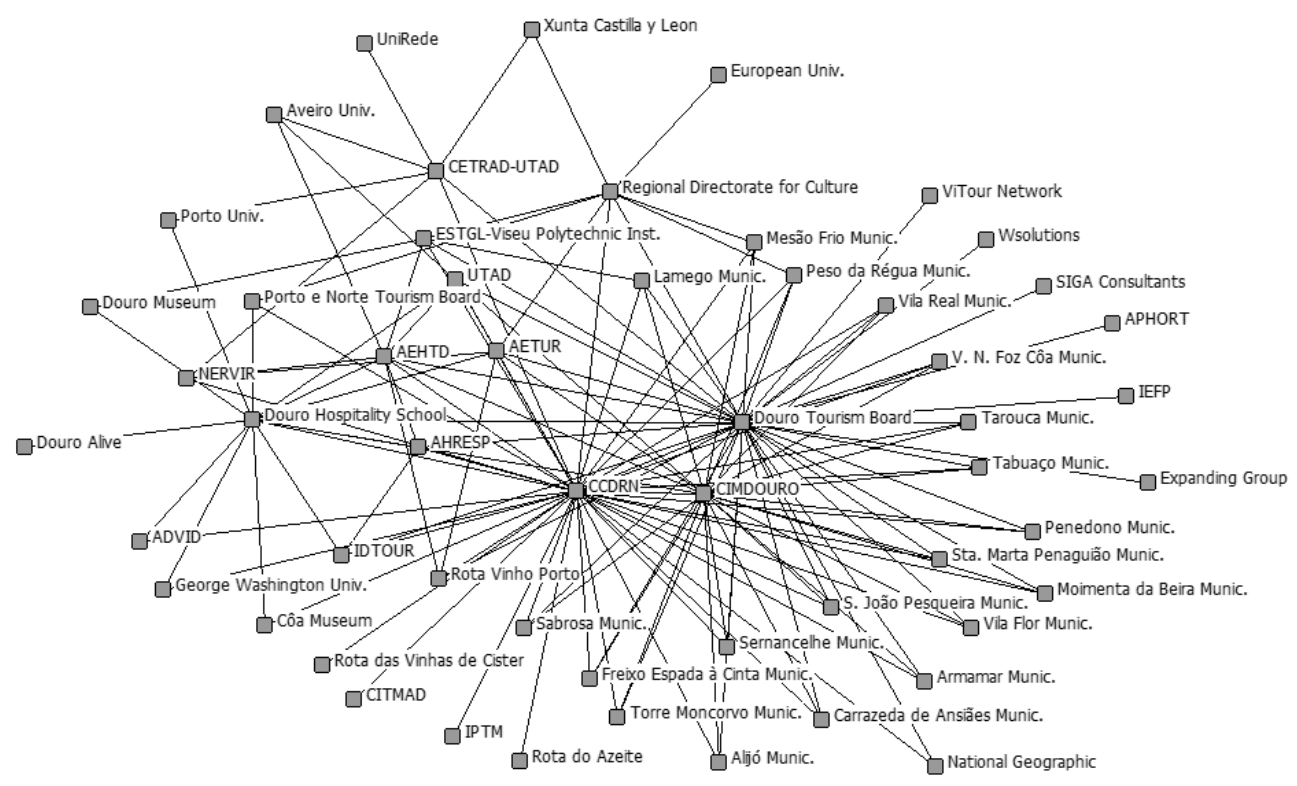

Figure 3.Institutional innovation network of Douro

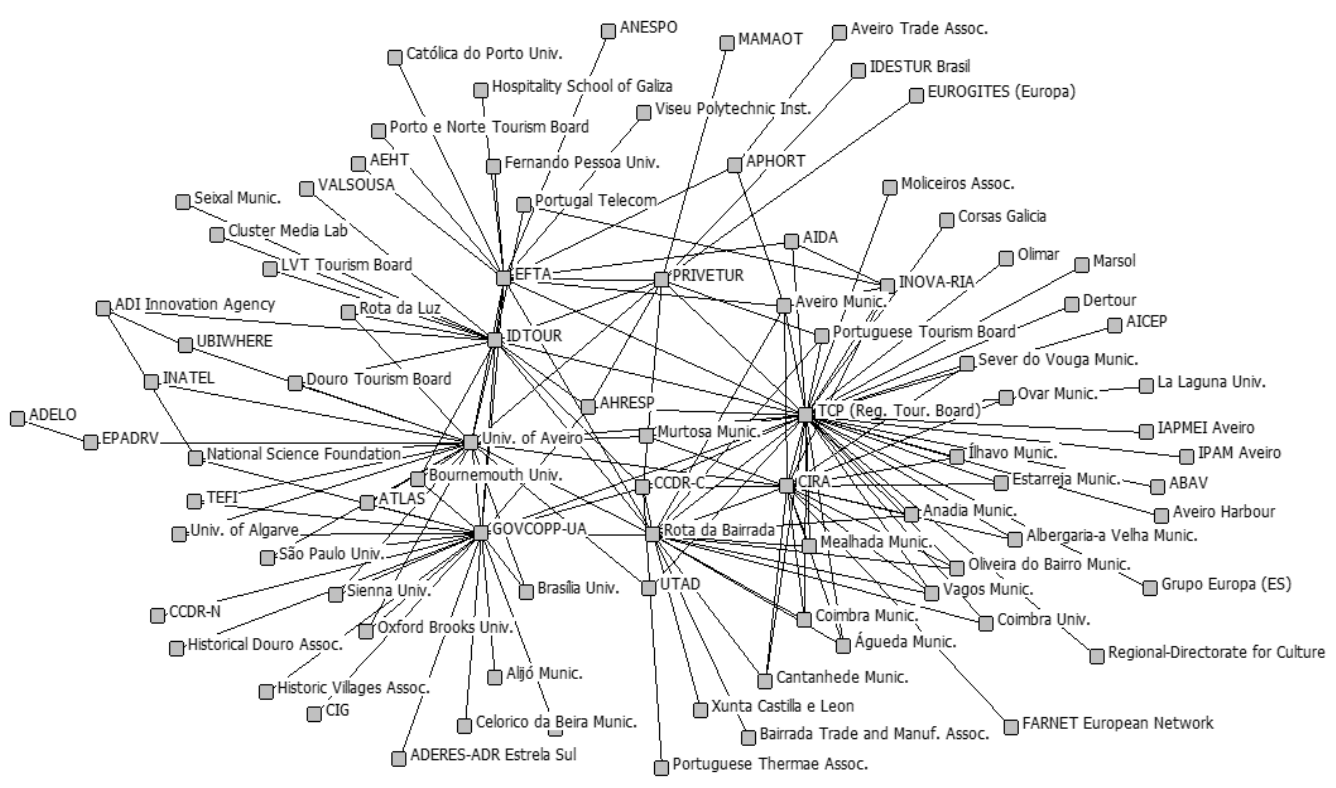

Figure 4. Institutional innovation network of Aveiro 
The network of Aveiro presents a distinct pattern. As shown in Figure 4, besides the Regional Tourism Board, regional knowledge producers represented by the University of Aveiro, its research unit and the tourism spinoff firm occupy central positions in regional tourism innovation. This occurs due to the strong relation they built with tourism institutions and firms located in the region. Also central are other public institutions and private business associations. These actors are the most powerful and active in the network regarding tourism innovation processes. They act as "hubs", access more information, knowledge, and resources and are likely to exert more control and influence over other actors, as they reach a larger number of individuals. Therefore, they are in advantageous positions for acquiring and sharing knowledge and to promote collective learning, fundamental processes underlying innovation. Moreover, these nodes, being the

Table 4. Degree and betweenness centrality

\begin{tabular}{|c|c|c|c|}
\hline \multicolumn{2}{|l|}{ Douro } & \multicolumn{2}{|c|}{ Aveiro } \\
\hline \multicolumn{4}{|c|}{ Degree Centrality } \\
\hline Institution & Degree & Institution & Degree \\
\hline CCDRN & $41(15 \%)$ & Regional Tourism Board & $41(13 \%)$ \\
\hline Douro Tourism Board & $37(13.5 \%)$ & $\begin{array}{l}\text { GOVCOPP-UA (Research } \\
\text { Unit) }\end{array}$ & $24(7.7 \%)$ \\
\hline $\begin{array}{l}\text { CIMDOURO (Assoc. of } \\
\text { Municipalities) }\end{array}$ & $24(8.8 \%)$ & University of Aveiro & $23(7.3 \%)$ \\
\hline Douro Hospitality School & $15(5.5 \%)$ & $\begin{array}{l}\text { CIRA (Assoc. of } \\
\text { Municipalities) }\end{array}$ & $20(6.4 \%)$ \\
\hline AEHTDOURO - Hotel Association & $10(3.7 \%)$ & Bairrada Wine Route & $19(6 \%)$ \\
\hline \multirow[t]{3}{*}{ Regional-Directorate for Culture } & $9(3.3 \%)$ & IDTOUR & $17(5.4 \%)$ \\
\hline & & EFTA (Vocational School) & $16(5.1 \%)$ \\
\hline & & $\begin{array}{l}\text { PRIVETUR (rural tourism } \\
\text { assoc.) }\end{array}$ & $10(3.2 \%)$ \\
\hline TOTAL & $49.8 \%$ & TOTAL & $54.1 \%$ \\
\hline \multicolumn{4}{|c|}{ Betweenness Centrality } \\
\hline Institution & Betweenness & Institution & Betweenness \\
\hline CCDRN & 610,37 & Regional Tourism Board & 1701,38 \\
\hline Douro Tourism Board & 537,29 & $\begin{array}{l}\text { GOVCOPP-UA (Research } \\
\text { Unit) }\end{array}$ & 906,41 \\
\hline Douro Hospitality School & 146,27 & University of Aveiro & 792,15 \\
\hline CETRAD-UTAD (Research Unit) & 106,55 & EFTA (Vocational School) & 720,31 \\
\hline $\begin{array}{l}\text { CIMDOURO (Assoc. of } \\
\text { Municipalities) }\end{array}$ & 100,53 & IDTOUR & 556,40 \\
\hline \multirow[t]{3}{*}{ Regional-Directorate for Culture } & 86,32 & Bairrada Wine Route & 389,87 \\
\hline & & $\begin{array}{l}\text { PRIVETUR (rural tourism } \\
\text { assoc.) }\end{array}$ & 272,09 \\
\hline & & $\begin{array}{l}\text { CIRA (Assoc. of } \\
\text { Municipalities) }\end{array}$ & 232,31 \\
\hline Mean betweenness & 109.7 & Mean betweenness & 241.5 \\
\hline Std. Deviation & 30.6 & Std. Deviation & 68.4 \\
\hline
\end{tabular}


most connected ones, are the most likely to acquire new connections as other actors join the network (Degenne \& Forse, 1999; Gay \& Dousset, 2005), because they present more relational activity. Conversely, actors with a lower degree of centrality are peripheral and endowed with less activity because they are isolated. Nonetheless, an actor that is peripheral in a network may be central in another network, reason why he should not be undervalued. He may be in the position of a broker, acting as an intermediary between two different networks.

Besides the degree, betweenness and closeness are useful measures to analyse centrality. Betweenness is a measure of intermediation, considering direct and indirect ties. It reflects the control over and access to the flow of resources. Most powerful actors are those who connect nodes or cliques that would otherwise be disconnected, presenting a higher innovative potential as they access information from different sources (Freeman, 1979). Table 4 includes the results of degree and betweenness centrality of both networks. The results confirm that are few central actors and that they are the same with the higher degree, apart from the knowledge producers of Douro that emerge in this context. Intermediation is performed to a large extent by public or governmental organisations, with knowledge institutions acquiring significant positions in what concerns the flow of resources, especially knowledge and expertise.

While in Douro, despite the variation, almost all actors present some betweenness centrality (only $32.7 \%$ have 0 ), in Aveiro the opposite occurs, as intermediation is concentrated in few actors $(77 \%$ have 0 betweenness). Power deriving from intermediation is more distributed in Douro, as most institutions do not depend on a small group to be connected or to access knowledge, skills, or other resources. In Aveiro the power belongs to a reduced clique on which most actors rely on to access resources. Knowledge sharing, collective learning, and innovation development are constrained by a few (most central) actors.

Closeness centrality is an important indicator of trust and proximity among the network members, which is a precondition for the development of territorial innovation. Tacit knowledge finds the best way to be spread among actors with higher closeness. These actors are potentially more innovative as they are the recipients of new knowledge. Moreover, they are likely to get fresh information sooner and to interact with all other nodes more quickly. Subsequently, they are also more embedded in the network (Uzzi, 1997) and have a higher ability to prevent control by other nodes. An actor may have few ties, but these may allow him to access a great number of other nodes more quickly, because he has the shortest path to all other nodes. While high betweenness means control of resources and actors, closeness represents the access to them (Freeman, 1979; Hanneman \& Riddle, 2005). There were found no significant differences in the nodes with higher closeness centrality, when compared to betweenness or degree. While in Douro the most prominent actors are government institutions and business associations, it is worth noting that, in Aveiro, knowledge and research organisations unveil significant importance by being highly proximate to all the network members. This situation is favourable for new knowledge dissemination throughout the entire network and to the development of innovations based on it. In both tourism innovation networks, centrality is concentrated in the same few actors.

Networks' cohesion refers to how well connected the social structure is, which has clear impacts on the flow of information, knowledge, and overall resources. The higher the level of cohesion, the more robust a network is, being less vulnerable to the exit of nodes. Considering that the access to knowledge is fundamental to the development of innovation, the existence of high connectivity increases the overall innovation performance. As mentioned, the density of the innovation network of Douro is of $9.2 \%$ and in Aveiro is of $4.2 \%$. Despite the fact that these values point towards sparse networks, they reveal to be above or very close to the results obtained in similar empirical studies mentioned above (Baggio et al., 2010; Scott, Baggio, et al., 2008; Scott, Cooper, et al., 2008). Nonetheless, the actors located in Douro configure a denser 
network than those located in Aveiro, which may indicate that knowledge and innovative ideas flow easier and reach a higher number of nodes.

Distance measures, such as the cluster coefficient, allow analysing the relative proximity between nodes and then to group them into homogeneous clusters, reason why they are frequently used in regional analysis (Costa, 1996). A cluster is defined as a group of high density within a network, referring to nodes that are more similar or proximate to one another than they are to other nodes. They are defined according to their contiguity and their separation from other clusters (Scott, 2000). Costa (1996) highlights the potential of cluster analysis for tourism research, namely for defining tourism regions, designing homogeneous tourism products and segmenting markets. In sociometric analysis, it allows to identify which organisations are closer to each other operating as cliques in terms of knowledge transfer, collective learning, and innovation development, as well as peripheral organisations. The clustering coefficient (CC) is used to measure the extent to which some actors present more activity, with many ties around their alters, while other ego networks present fewer ties (Hanneman \& Riddle, 2005; Koput, 2010).

Table 5. Clustering Coefficient in Douro and Aveiro's tourism innovation networks (real and random)

\begin{tabular}{lll}
\hline Region & $\begin{array}{l}\text { Real } \\
\text { Network }\end{array}$ & $\begin{array}{l}\text { Random } \\
\text { Network }\end{array}$ \\
\hline Douro & 0,57 & 0,09 \\
Aveiro & 0,68 & 0,05 \\
\hline
\end{tabular}

Both networks present good levels of clustering, significantly higher than the reference values of the random networks, unveiling a pattern of cohesive social structures. However, as showed in table 5, Aveiro's tourism innovation network is more clustered that Douro and thus it is in a more favourable position ( $67.7 \%$ against $56.6 \%)$. The higher the clustering coefficient, the closer the actors are to each other. Their relationships are thus more embedded, knowledge is easily widespread and there is a higher level of trust 48 among individuals and organisations, raising the potential for collective learning and for the development of networked tourism innovation. It also builds a more robust and less vulnerable network. Highly clustered networks are characterised by stronger relationships are by being less 'damaged' due to the exit of one or more actors, because actors can find alternative paths to make the connections active.

\section{The Spatiality of Innovation Relationships}

As mentioned, the higher the diversity of actors in a network, the stronger is the potential for new and fresh ideas to emerge, leading to an innovative environment. The network of Douro integrates a higher number of local and regional actors. Together, they represent $78 \%$ of the overall network. Only 12 nodes are located at national or international levels. This unveils a low outward orientation. Conversely, the network of Aveiro presents a more balanced structure, considering that there is a more equitable distribution of actors from different locations, indicating an interesting dynamic between all geographical levels. Nonetheless, actors operating at national level stand out with $33 \%$ of the total. Together with the international actors, they represent $55 \%$ of the entire network. This assures that new knowledge and resources enter the network preventing situations of lock-in and decline. The more advanced stage of development that characterises Aveiro as a tourism destination may certainly influence the presence of these external actors within tourism innovation processes. In fact, as argued by Weidenfeld (2013) and Aldebert, Dang, and Longhi (2011), the internet and the growing human mobility have been spanning the boundaries between partners and changing the external environment of organisations, increasing the connectivity within tourism networks. Aveiro appears to be seizing the opportunities brought by these dynamics.

Besides the composition of the networks, it is fundamental to consider the spatiality of the relations established among the actors. To conduct this analysis, the Internal-External Index (E-I Index) was computed, as developed by Krackhardt and Stern (1988). E-I index can range between -1 and 1 . $A-1$ value indicates 
that all ties are established between actors from the same group and +1 reveals that all ties are external to the group. A high E-I value will indicate more and closer ties between groups than within the group of membership. To determine the geographical embeddedness of the relationships established towards the development of tourism innovation, organisations were classified as (i) local, (ii) regional, (iii) national, and (iv) international.

The results presented in Table 6 shows that both networks have positive indexes, meaning that the ties established with institutions from other geographical levels exceed those developed within the same geographical location. This is more significant in Aveiro (E-I index $=0.643$ ), where the links established with institutions from other regions (258) largely exceed the internal ones (56). In Douro, the ratio is less expressive $(\mathrm{E}-\mathrm{I}$ index $=0.212)$, as the 166 external links are not very far from the internal ones (108). Considering the already mentioned composition of the networks, these values are easily explained. The network of Douro is mainly comprised of local and regional actors and thus, they are also engaged in the majority of the developed ties. The overall pattern of cooperation is mainly characterised by the links established between regional actors (108 ties) and between the local and regional organisations (62 ties), corresponding to a density of $23.4 \%$ and $13.4 \%$, respectively. The ties with national and international organisations are residual. This unveils a high regional embeddedness of relations within tourism innovation processes, especially due to the contribution of local and regional public bodies that occupy the most central positions.

The structure of the geographical distribution of ties in Aveiro is quite different from Douro. Regional actors are indeed the propellers of the tourism innovation dynamics. However, they are connected with organisations from all the geographic levels. The links among regional actors are the most significant (62 ties, with a density of $18.1 \%$ ), followed by the ties between regional and local nodes, in a total of 56 (density of 14\%). National and regional organisations have densities of $5.8 \%$ and $6.6 \%$. Also in this network, the most central actors are responsible for these values. But here, besides the public bodies, the University of Aveiro, its research unit and the spin-off firm stand out as the main contributors to the outwards orientation of this innovation network, as they are engaged in several national and international connections. This network also shows a significant level of regional embeddedness. However, it has the advantage of being engaged in external relationships that introduce new knowledge and foster innovation. Hoarau and Kline (2014) and Booyens and Rogerson (2017) also conclude that networking linkages with non-local or extra-regional strategic partners are highly beneficial for learning and innovation. This scenario brings important contributions to regional innovation. The links to external actors allows the entrance of new knowledge that gives place to innovation, and the links within the region makes possible that this new knowledge and ideas are spread to a significant part of the actors in the network.

The relevant share of relations established between actors with a regional dimension, observed in both structures, confirms the findings of Bellandi and Caloffi (2010) who, when analysing the location of the various actors in an innovation network, concluded that a significant part of the links occurred among agents localised within the same geographical context.

Relationships among Different Organisations Besides the spatiality of the relations towards

Table 6. Geographical embeddedness of tourism innovation networks (External-Internal Index)

\begin{tabular}{lllll}
\hline Metric & $\begin{array}{l}\text { Douro } \\
\text { Real } \\
\text { Network }\end{array}$ & $\begin{array}{l}\text { Douro } \\
\text { Random } \\
\text { Network }\end{array}$ & $\begin{array}{l}\text { Aveiro } \\
\text { Real } \\
\text { Network }\end{array}$ & $\begin{array}{l}\text { Aveiro } \\
\text { Random } \\
\text { Network }\end{array}$ \\
\hline E-I Index geo $_{\text {Internal Ties }}$ & 0.212 & 0.390 & 0.643 & 0.529 \\
External Ties & 108 & $\mathrm{X}$ & 56 & $\mathrm{x}$ \\
\hline
\end{tabular}


innovation, it was also an objective to unveil if the established links occur mostly between organisations of the same or of different types. The E-I Index regarding groups of different organisations (E-I Index org) was computed in order to conclude on the embedding of relations towards the development of innovations in a specific group of organisations or, on the contrary, if the organisations search for partners with a different scope of action. In this context, five groups were established: (i) knowledge organisations; (ii) public organisations; (iii) consultants; (iv) business associations; and (v) innovation support agencies.

The results presented in table 7 demonstrate that in the tourism innovation network of Aveiro the links established for innovation purposes with organisations from different groups exceed those established within the group of belonging $(E-I$ index $=0,108)$. Despite the fact that the links among public organisations stand out (72 ties), the density of $4.9 \%$ is far from being the highest in the network. It is worth mentioning the 64 ties established amongst knowledge institutions (density of $11.7 \%$ ), contributing to the dissemination of scientific knowledge on tourism which is one of the main sources of innovation. The University of Aveiro and its tourism research unit play a paramount role in linking these institutions. The links between knowledge institutions and public agencies are also relevant, although they can be significantly improved (density is 2.8), as well as those between public agencies and business associations.

Conversely, the organisational network of the Douro is characterised by a majority of internal ties, as most links are established between organisations of the same type and scope (E-I index of $-0,182)$. Specifically, the most relevant dynamics in terms of cooperation towards the development of tourism innovation result from the ties established among public agencies (138 ties with a density of $17 \%$ ), between these and knowledge producers (19 ties, 7,3\% density) and among knowledge producers (total of 14 ties and a density of $19.4 \%$, the highest observed in this analysis).

\section{Conclusion}

The purpose of this paper was to analyse the structure and the dynamics of institutional tourism innovation networks at regional level. It is based on Social Network Analysis, exploring its contribution for the study of networked innovation in tourism destinations.

Network theory has become fashionable in the last years. That results from a changing world, characterised by the fragmented nature of industry, the dominance of service economy, the emergence of SMES and the development of new economic structures structured as clouds of organisations. In result, networks are becoming the new informal governance structures that prompt organisations to gain muscle, stability, and increased capacity to innovate (Costa, 1996; Brandão \& Costa, 2012).

The contribution of this paper is two-fold. First, it elaborates and expands the quantitative methods to innovation networks in tourism providing a framework for the analysis of networked tourism innovation. In this regard, the adopted approach brings empirical validation on the role played by institutional networks. Second, it unveils practical ways to foster regional development and destination competitiveness.

The analysed regions present different social structures in terms of their composition (type

Table 7. Organisational embeddedness of tourism innovation networks (External-Internal Index)

\begin{tabular}{lcccc}
\hline Metric & $\begin{array}{c}\text { Douro } \\
\text { Real } \\
\text { Network }\end{array}$ & $\begin{array}{c}\text { Douro } \\
\text { Random } \\
\text { Network }\end{array}$ & $\begin{array}{c}\text { Aveiro } \\
\text { Real } \\
\text { Network }\end{array}$ & $\begin{array}{c}\text { Aveiro } \\
\text { Random } \\
\text { Network }\end{array}$ \\
\hline E-I Indexorg & -0.182 & 0.328 & 0.108 & 0.388 \\
Internal Ties & 162 & $\mathrm{X}$ & 140 & $\mathrm{x}$ \\
External Ties & 112 & $\mathrm{x}$ & 174 & $\mathrm{x}$ \\
\hline
\end{tabular}


and location of actors) and dynamics (patterns of cooperation), each providing different benefits for tourism innovation. The network of Douro is characterised by being smaller, inward-oriented, with many internal links and less external connections. The more inward orientation and the significant regional embeddedness of the innovation process in Douro brings benefits that relate to a higher internal cohesion, mutual trust and increased collaboration among local actors, facilitating the flow of knowledge and ideas. However, it may be constraining innovation due to the lack of diversity of the network members and relationships, as it prevents the access to new knowledge into the system. Douro is an inland destination in an earlier stage of development that, despite of its recent growth and acknowledgement as an international destination, does not benefits from the economic polarisation of coastal, developed, sea \& sun destinations. Therefore, it is important that strong, solid innovation networks are developed to gain competitive advantages. The tourism development of Douro was mastered and funded by regional government structures, and this may be the reason why public authorities have such a strong centrality. However, it is concluded that diversified innovation networks provide a more innovationfriendly regional environment. The prominence of non-local actors, as well as of knowledge producers alongside public institutions is positively connected to a higher regional innovative potential, since tourism firms and organisations can access different types of knowledge from distinct sources, fostering its combination into new tourism products and services. However, it is fundamental that internal (regional) ties are still present and equally strong, enabling the diffusion of knowledge throughout the network, provided it is densely connected. Networks provide important opportunities for the development of innovation. However, attention should be given to critical factors, such as (i) the nature of its members, assuring the diversity of members aiming at the presence between public and private organisations, knowledge producers and innovation agencies; (ii) the location of the actors, with a balance between internal and external ties.
Additionally, the analysis of centrality brings important insights. In both regions, prominence and power are concentrated in a few nodes. These have a very high responsibility in the development of conditions for innovation to occur in the tourism destination. It was hypothesised that these most central actors are those performing destination management functions. This was confirmed for the network of Douro, however, in Aveiro, it was observed that the DMO has a significant position, but prominence and power is shared with knowledge producers, namely research centres and universities. While public authorities have an important role in developing tourism policies that influence innovation and in the promotion and marketing of tourism products and destinations, the knowledge producers create the necessary knowledge for innovation to emerge, supporting the development of new products and services. These universities and R\&D institutions are also the main responsible for connecting the network to external (international) actors and thus they stand as the main entry of new and fresh knowledge into the network, increasing the innovation performance of regional tourism agents. Considering that Aveiro has a higher innovation performance, it is strongly recommended that tourism destinations create stronger ties in the university-industry relation.

Tourism firms, destination management organisations and governance structures should acknowledge that there is a need to introduce innovation policies and strategies supporting the creation of innovation networks that comprise tourism firms and organisations and establish solid links with internal and external actors, as well as cross-sectoral links. The higher the diversity of the network, the higher may be the innovative potential of tourism firms and regions.

Finally, it should be mentioned the absence of organisations representing local communities in both networks. Considering that many successful tourism innovations are experiences based on local traditions and regional authenticity, it is of foremost importance that local residents are part of the innovation process and regional development. 


\section{Limitations and suggestions for further research}

This paper has a number of limitations. First, the network analysis is only applied to institutions. Further research should be made on this topic, including tourism firms as well, and draw conclusions on the overall innovation dynamics occurring in tourism destinations. A deeper investigation should also be made on the forms of participation of local communities in regional tourism innovation. In addition, this paper is exploratory in nature, as it is based on the analysis of two regions. Despite the fact that the 30 surveyed institutions represent the population, it is a small number of questionnaires. Similar studies should be conducted in other regions with different political and cultural settings, and in destinations offering different tourism products. Future studies would also benefit from a larger sample. It is also suggested further studies over time, in order to assess the diachronic dynamics of tourism innovation networks.

\section{References}

Acs, Z. J., \& Audretsch, D. B. (1988). Innovation in Large and Small Firms: An Empirical Analysis. American Economic Review, 78(4), 678-690.

Aldebert, B., Dang, R. J., \& Longhi, C. (2011). Innovation in the tourism industry: The case of Tourism. Tourism Management, 32(5), 1204-1213. doi:10.1016/j.tourman. 2010.08.010

Amin, A., \& Thrift, N. (1995). Globalization, Institutional Thickness and the Local Economy. In P. Healy, S. Cameron, \& A. Davoudi (Eds.), Managing Cities: The New urban Context Chichester: John Wiley.

Archibugi, D., Howells, J., \& Michie, J. (1999). Innovation Systems and Policy in a Global Economy. In D. Archibugi, J. Howells, \& J. Michie (Eds.), Innovation Policy in a Global Economy (pp. 1-16). Cambridge Cambridge University Press.

Aureli, S., \& Forlani, F. (2015). The effects of formal networks on territorial tourism offers. Current usage of network contracts in Italy. European Journal of Tourism Research, 10, 76-94.

Aydalot, P. (1986). Milieux innovateurs en Europe. Paris: GREMI.
Baggio, R. (2008). Network analysis of a tourism destination. (Ph.D. in Tourism), University of Queensland, Queensland, Australia.

Baggio, R. (2017). Network science and tourism - the state of the art. Tourism Review, 72(1), 120-131

Baggio, R., \& Cooper, C. (2008). Knowledge management and transfer in tourism: an Italian case. Paper presented at the paper presented at IASK Advances in Tourism Research (ATR 2008), Aveiro, Portugal, 26-28 May.

Baggio, R., \& Cooper, C. (2010). Knowledge transfer in a tourism destination: the effects of a network structure. The Service Industries Journal, 30(8), 1757-1771.

Baggio, R., Scott, N., \& Cooper, C. (2010a). Improving tourism destination governance: a complexity science approach. Tourism Review, 65(4), 51-60.

Baggio, R., Scott, N., \& Cooper, C. (2010b). Network Science: a Review focused on Tourism. Annals of Tourism Research, 37(3), 802-827.

Bellandi, M., \& Caloffi, A. (2010). An Analysis of Regional Policies Promoting Networks for Innovation. European Planning Studies, 18(1), 67 - 82.

Bonacich, P. (1987). Power and centrality: a family of measures. The American Journal of Sociology, 92, 1170-1182.

Booyens, I., \& Rogerson, C. M. (2016). Unpacking the geography of tourism innovation in Western Cape Province, South Africa. Bulletin of Geography, 31 (31), 19-36. doi:10.1515/bog-2016-0002

Booyens, I., \& Rogerson, C. M. (2017). Networking and learning for tourism innovation: evidence from the Western Cape. Tourism Geographies, 19(3), 340361.

Borgatti, S. P., Everett, M. G., \& Freeman, L. C. (2002). Ucinet for Windows: Software for Social Network Analysis. Harvard, MA: Analytic Technologies.

Borgatti, S. P., \& Foster, P. (2003). The network paradigm in organizational research: A review and typology. Journal of Management, 29(6), 991-1013.

Borgatti, S. P., Jones, C., \& Everett, M. G. (1998). Network measures of social capital. Connections, 21(2), 27-36. 
Bramwell, B. (2006). Actors, Networks and Tourism Policies. In D. Buhalis \& C. Costa (Eds.), Tourism Management Dynamics Trends, Management and Tools. London: Elsevier.

Brandão, F., \& Costa, C. (2012). Regional Innovation Systems and Tourism: a Conceptual Approach. Journal of Tourism \& Development, 17/18(2), 647-660.

Breda, Z., Costa, R., \& Costa, C. (2005). Clustering and networking the tourism development process: a market driven approach for a small backwards tourist region located in central Portugal (Caramulo). In C. S. Petrillo \& J. Swarbrook (Eds.), Atlas Annual Conference: Networking and Partnerships in Destination Development and Management. (pp. 469-484) Naples: Atlas.

Breda, Z., Costa, R., \& Costa, C. (2006). Do clusters and networks make small places beautiful? The case of Caramulo (Portugal). In L. Lazzeretti \& C. S. Petrillo (Eds.), Tourism Local Systems and Networking (pp. 67-82). London: Elsevier.

Buhalis, D. (2000). Marketing the competitive destinations of the future. Tourism Management, 21(1), 97-116. doi:10.1016/ S0261-5177(99)00095-3

Burt, R. S. (1992). Structural Holes: The Social Structure of Competition. Cambridge and Iondon: Harvard University Press.

Camagni, R. (Ed.) (1991). Innovation Networks: Spatial Perspectives. London and New York: GREMI/Belhaven Press.

Carlsson, B., Jacobsson, S., Holmén, M., \& Rickne, A. (2002). Innovation systems: analytical and methodological issues. Research Policy, 31, 233-245.

Castells, M. (2010). The rise of the network society (2nd ed.). Chichester, West Sussex; Malden, MA: Wiley-Blackwell.

Chaminade, C., \& Roberts, H. (2002). Social Capital as a Mechanism: Connecting Knowledge Within and Across Firms. Paper presented at the Third European Conference on Organizational Knowledge, Learning and Capabilities - OKLC, Athens, Greece, April 2002.

Child, J., Faulkner, D., \& Tallman, S. B. (2005). Cooperative Strategy: Managing Alliances, Networks and Joint Ventures. Oxford: Oxford University Press.
Clar, G., Sautter, B., \& Hafner-Zimmermann, S. (2008). Strategic Cluster Development: Applying Strategic Policy Intelligence to create a Joint Research Agenda. Background paper for the CReATE project. Retrieved from http://www.letscreate.eu/fileadmin/_create/downloads/del -1-2_cluster-backgroundpaper_revised_final.pdf

Coleman, J. (1988). Social Capital in the creation of Human Capital. American Journal of Sociology, 94, 95-121.

Considine, M., Lewis, J. M., \& Alexander, D. (2009). Networks, Innovation and Public Policy. Politicians, Bureaucrats and the Pathways to Change inside Government. London: Palgrave Macmillan.

Cooke, P., \& Morgan, K. (1998). The associational economy: firms, regions, and innovation. Oxford: Oxford University Press.

Costa, C. (1996). Towards the Improvement of the Efficiency and Effectiveness of Tourism Planning and Development at the Regional Level: Planning, Organisations and Networks. The Case of Portugal. (Ph.D. Thesis), University of Surrey, England.

Costa, C., Breda, Z., Costa, R., \& Miguéns, J. (2008). The Benefits of Networks for Small and Medium Sized Tourism Enterprises. In N. Scott, R. Baggio, \& C. Cooper (Eds.), Network Analysis and Tourism: From Theory to Practice (pp. 96-114). Clevedon: Channel View Publications.

Degenne, A., \& Forse, M. (1999). Introducing Social Networks. London: Sage.

Dredge, D. (2005). Networks and Innovation in Lake Macquarie. In D. Carson \& J. Macbeth (Eds.), Regional Tourism Cases: Innovation in Regional Tourism (pp. 6168). Gold Coast Sustainable Tourism Cooperative Research Center.

Dredge, D. (2006). Policy networks and the local organisation of tourism. Tourism Management, 27(2), 269-280.

Eurostat. (2016). The Community Innovation Survey $2016 \quad$ - Methodological recommendations. Retrieved from https://circabc.europa.eu/webdav/CircaBC /ESTAT/infoonstatisticsofsti/Library/metho dology/community_innovation/CIS\%20201 6/CIS\%202016\%20Methodological\%20re 
commendations.pdf (accessed 6 February 2017)

Fagerberg, J. (2006). Innovation. A Guide to the Literature. In J. Fagerberg, D. C. Mowery, \& R. R. Nelson (Eds.), The Oxford Handbook of Innovation (pp. 1-26). Oxford: Oxford University Press.

Favre-Bonté, V., Gardet, E., \& ThevenardPuthod, C. (2016). Inter-organizational network configurations for ski areas innovations. European Journal of Innovation Management, 19(1), 90-110. doi:10.1108/EJIM-04-2014-0039

Fitjar, R. D., \& Rodríguez-Pose, A. (2015). Networking, context and firm-level innovation: cooperation through the regional filter in Norway. Geoforum, 63, 25-35.

Freeman, L. C. (1979). Centrality in Social Networks: Conceptual Clarification. Social Networks, 1, 215-239.

Gay, B., \& Dousset, B. (2005). Innovation and network structural dynamics: Study of the alliance network of a major sector of the biotechnology industry. Research Policy, 34, 1457-1475.

Gibson, L., Lynch, P., \& Morrison, A. (2005). The local destination tourism network: Development issues. Tourism and Hospitality Planning and Development, 2(2), 87-99.

Gomezelj, D. O. (2016). A systematic review of research on innovation in hospitality and tourism. International Journal of Contemporary Hospitality Management, 28(3), 516-558. doi:10.1108/IJCHM-102014-0510

Granovetter, M. (1973). The Strength of Weak Ties. American Journal of Sociology, 78 (6), 1360-1380. doi:10.2307/2776392

Granovetter, M. (1983). The Strength of Weak Ties: a Network Theory Revisited. Sociological Theory, 1, 201-233.

Halme, M. (2001). Learning for sustainable development in tourism networks. Business Strategy and the Environment, 10(2), 100-114. doi:10.1002/bse. 278

Hanneman, R. A., \& Riddle, M. (2005). Introduction to Social Network Methods

Haythornthwaite, C. (1996). Social Network Analysis: An Approach and Technique for the Study of Information Exchange.
Library and Information Science Research, 18 323-342.

Hjalager, A.-M. (2010). A review of innovation research in tourism. Tourism Management, 31(1), 1-12. doi:10.1016/ j.tourman. 2009.08.012

Hjalager, A. M. (2014). Disruptive and sustaining innovation: the case of rural tourism. In G. A. Alsos, D. Eide, \& E. L. Madsen (Eds.), Handbook of Research on Innovation in Tourism Industries (pp. 5683). Cheltenham: Edward Elgar.

Hoarau, H., \& Kline, C. (2014). Science and industry: sharing knowledge for innovation. Annals of Tourism Research, 16(1), 44-61. doi:http://dx.doi.org/10.1016 /j.annals.2014.01.005

Hotz-Hart, B. (2000). Innovation Networks, Regions and Globalization. In G. L. Clark, M. P. Feldman, \& M. S. Gertler (Eds.), The Oxford Handbook of Economic Geography (pp. 432-450). Oxford: Oxford University Press.

Howells, J. R. L. (2002). Tacit Knowledge, Innovation and Economic Geography. Urban Studies, 39(5/6), 871-884. doi:10.1080/00420980220128354 39:

Karl, M., \& Reintinger, C. (2017). Investigating Tourists' Destination Choices - An Application of Network Analysis. European Journal of Tourism Research, 15, 112130.

Kline, S., \& Rosenberg, N. (1986). An Overview of Innovation. In R. Landau \& N. Rosenberg (Eds.), The Positive Sum Strategy: Harnessing Technology for Economic Growth (pp. 275-304). Washington, DC: National Academy Press.

Knoke, D., \& Kuklinski, J. H. (1982). Network Analysis. London: Sage.

Kolaczyk, E. D. (2009). Statistical Analysis of Network Data: Methods and Models. Boston: Springer.

Koput, K. W. (2010). Social capital: An Introduction to Managing Networks. Cheltenham: Edward Elgar.

Krackhardt, D. (1992). The Strength of Strong Ties: The Importance of Philos in Organizations. In N. Nohria \& R. Eccles (Eds.), Networks and Organizations: Structure, Form, and Action (pp. 216-239). Boston: Harvard Business School Press. 
Krackhardt, D., \& Stern, R. N. (1988). Informal networks and organisational crisis: an experimental simulation. Social Psychology Quarterly, 51, 123-140.

Lazzeretti, L., \& Petrillo, C. S. (Eds.). (2006). Tourism Local Systems and Networking. Amsterdam: Elsevier.

Liu, B. S.-C., Madhavan, R., \& Sudharshan, D. (2005). DiffuNET: The impact of network structure on diffusion of innovation. European Journal of Innovation Management, 8(2), 240-262.

Lundvall, B.-Â. (1992). National Systems of Innovation: Towards a Theory of Innovation and Interactive Learning. London: Pinter.

Lundvall, B.-Å., \& Borrás, S. (1997). The globalising learning economy: implications for innovation policy. Luxembourg: European Commission, DG Science, Research and Development.

Malerba, F. (2005). Sectoral systems of innovation: a framework for linking innovation to the knowledge base, structure and dynamics of sectors. Economics of Innovation and New Technology, 14(1), 63 - 82.

Michael, E. J. (Ed.) (2007). Micro-clusters and Networks: The Growth of Tourism. Oxford: Elsevier.

Mowery, D. C. (1999). America's Industrial Ressurgence? An Overview US Industry in 2000: Studies in Competitive Performance (pp. 1-16). Washington, DC: National Academiy Press.

Narduzzo, A., \& Volo, S. (2016). Tourism innovation: when interdependencies matter. Current Issues in Tourism, 1-7. doi:10.1080/13683500.2016.1214111

Nooteboom, B. (2004). Inter-firm Collaboration, Learning and Networks: An integrated approach. London: Routledge.

Novelli, M., Schmitz, B., \& Spencer, T. (2006). Networks, clusters and innovation in tourism: A UK experience. Tourism Management, 27(6), 1141-1152. doi:10.1016/j.tourman.2005.11.011

Paget, E., Dimanche, F., \& Mounet, J.-P. (2010). A tourism innovation case: An Actor-Network Approach. Annals of Tourism Research, 37(3), 828-847.

Pavlovich, K. (2003). The evolution and transformation of a tourism destination network: the Waitomo Caves, New Zealand. Tourism Management, 24(2), 203-216.

Pavlovich, K. (2008). Network Governance and Connectivity: A Case Study. In N. Scott, R. Baggio, \& C. Cooper (Eds.), Network Analysis and Tourism: From Theory to Practice: Channel View Publications.

Pechlaner, H., Fischer, E., \& Hammann, E.-M. (2006). Leadership and Innovation Processes-Development of Products and Services Based on Core Competencies. Journal of Quality Assurance in Hospitality \& Tourism, 6(3), 31 - 57.

Petrillo, C. S., \& Swarbrooke, J. (Eds.). (2005). Networking and Partnership in Destinations and Development Management (Vol. II). Naples: Enzo Albano.

Polenske, K. R. (2007). The economic geography of innovation. Cambridge, UK; New York: Cambridge University Press.

Powell, W., Koput, K. W., \& Smith-Doerr, L. (1996). Interorganizational Collaboration and the Locus of Innovation: Networks of Learning in Biotechnology. Administrative Science Quarterly, 41, 116-145.

Powell, W. W., \& Grodal, S. (2006). Networks of Innovators. In J. Fagerberg, D. C. Mowery, \& R. Nelson (Eds.), The Oxford Handbook of Innovation. Oxford: Oxford University Press.

Presenza, A., \& Cipollina, M. (2010). Analysing tourism stakeholders networks. Tourism Review, 65(4), 17-30.

Rønningen, M. (2010). Innovative processes in a nature-based tourism case: The role of a tour-operator as the driver of innovation. Scandinavian Journal of Hospitality and Tourism, 10(3), 190-206. doi:10.1080/ 15022250.2010 .491255

Rothwell, R. (1994). Towards the Fifthgeneration Innovation Process. International Marketing Review, 11(1), 731. doi:10.1108/02651339410057491

Saxena, G. (2005). Relationships, networks and the learning regions: Case evidence from the Peak District National Park. Tourism Management, 26, 277-289.

Saxena, G., \& Ilbery, B. (2008). Integrated rural tourism: A border case study. Annals of Tourism Research, 35(1), 233-254. 
Scott, J. (2000). Social Network Analysis: A Handbook. London: Sage.

Scott, N., Baggio, R., \& Cooper, C. (2008). Network Analysis and Tourism: From Theory to Practice. Clevedon: Channel View Publications.

Scott, N., Cooper, C., \& Baggio, R. (2008). Destination Networks: Four Australian Cases. Annals of Tourism Research, 35(1), 169-188.

Sørensen, F. (2007). The Geographies of Social Networks and Innovation in Tourism. Tourism Geographies, 9(1), 2248. doi:10.1080/14616680601092857

Sundbo, J., Orfila-Sintes, F., \& Sørensen, F. (2007). The innovative behaviour of tourism firms - comparative studies of Denmark and Spain. Research Policy, 36, 88-106. doi:10.1016/j.respol.2006.08.004

Swarbrooke, J., Smith, M., \& Onderwater, L. (Eds.). (2004). Networking and Partnership in Destinations and Development Management: ATLAS Reflections 2004. Arnhem: ATLAS.

Tinsley, R., \& Lynch, P. (2001). Small Tourism Business Networks and Destination Development. International Journal of Hospitality Management, 20, 367-378.

UNSD, EUROSTAT, OECD, \& UNWTO. (2008). 2008 Tourism Satellite Account: Recommended Methodological Framework. Retrieved from http://unstats.un.org/unsd/statcom/doc08/ BG-TSA.pdf

Uzzi, B. (1997). Social Structure and Competition in Interfirm Networks: The
Paradox of Embeddedness. Administrative Science Quarterly, 42(1), 35-67.

Vonortas, N. S. (2009). Innovation Networks in Industry. In F. Malerba \& N. S. Vonortas (Eds.), Innovation Networks in Industries (pp. 27-44). Cheltenham: Edward Elgar.

Wasserman, S., \& Faust, K. (1994). Social Network Analysis: Methods and Applications. Cambridge: Cambridge University Press.

Watts, D. J., \& Strogatz, S. H. (1998). Collective dynamics of 'small-world' networks. Nature, 393, 440-442.

Weidenfeld, A. (2013). Tourism and cross border regional innovation systems. Annals of Tourism Research, 42, 191-213. doi:10.1016/j.annals.2013.01.003

Weidenfeld, A., \& Hall, C. M. (2014). Tourism in the development of regional and sectoral innovation systems. In A. A. Lew, C. M. Hall, \& A. M. Williams (Eds.), The Wiley Blackwell Companion to Tourism (pp. 578588). Chichester: Wiley Blackwell.

Zach, F. (2016). Collaboration for Innovation in Tourism Organizations. Journal of Hospitality \& Tourism Research, 40(3), 271.

Zach, F. J., \& Hill, T. L. (2017). Network, knowledge and relationship impacts on innovation in tourism destinations. Tourism Management, 62(Supplement C), 196-207. doi: https://doi.org/10.1016/j. tourman.2017.04.001 